Sign Systems Studies 29.1, 2001

\title{
Wilderness from an ecosemiotic perspective
}

\author{
Christina Ljungberg \\ English Seminar, Zürich University \\ Plattenstrasse 47, CH-8032 Zürich, Switzerland \\ e-mail: cljung@es.unizh.ch
}

\begin{abstract}
Wilderness" is a concept which has undergone a radical change in recent years. Owing to the scale of global destruction of the wilderness and its various ecosystems, the idea of wilderness has been transformed from its original negative sense as an Other into a matter of public concern. This as replaced the understanding of "wilderness" not only as a place but as a category closely linked with the development of human culture. As the result of human practice and representation, nature is thus also political. Models and concepts of nature in the creative arts can be indicative of a certain culture's relationship with nature, as they communicate prevailing ideologies. This is particularly pertinent to concepts of nature in Canada where wilderness includes vast tracts of forests, lakes and an Arctic North, which has led to a distinctively Canadian relationship between Canadians and their natural environment. The change in the literary representations of interactions between humankind and environment in Canadian fiction - from the "double vision" resulting from the view of the wilderness both as a threatening Other and free space; to the view of threatened nature as a means of identification; and, finally, as a postmodern place of transgression and possibility - invites questions about both the semiotic threshold between nature and culture, and about the function of boundaries in the constitution of identity.
\end{abstract}

\section{1. "Wilderness" as a cultural concept}

The concept of "wilderness" has undergone a radical change in recent years. The scale of the global destruction of the natural environment and its various ecosystems has transformed the idea of wilderness from a negative concept to a matter of public concern, since its survival is intricately linked with the survival of our own habitat. A 
growing awareness of the irreversible implications of the destruction of natural spaces by unprecedented forms of human interference with nature has helped shape a new sensibility for our dependency on nature; it has also replaced the understanding of "wilderness" not only as a place, but as a category with which humans are closely linked, and whose ecological sign processes need to be carefully interpreted.

The study of these sign processes is the focus of ecosemiotics, which, according to Winfried Nöth (2001a), is the study of "environmental semiosis", i.e., "the sign processes which relate organisms to their natural environment". Situated at the crossroads between the semiotics of nature and the semiotics of culture, ecosemiotics focuses specifically on the way in which these interactions are determined by signs and processes of semiosis. Hence, although it is most closely related to the semiotic fields of biosemiotics, zoosemiotics and cultural semiotics, ecosemiotics also concerns aesthetics, the visual arts, literature, hermeneutics and theology. The definition of ecosemiotics as "the semiotics of the relationship between nature and culture" has also been proposed by Kalevi Kull (1998: 350), who includes within ecosemiotics the study of the "semiotic aspects of place and role of nature for humans" and the extent of our communication with nature. Locating ecosemiotics in that "part of the semiotics of culture which investigates human relationships to nature which have a semiosic (sign-mediated) basis", Kull also suggests that ecosemiotics may include "the context-dependence of the valuation of nature, differences in seeing and understanding it" (ibid.: 351).

Hence, nature is understood as the result of human practice and of representation. It is thus also political; and, as Carolyn Merchant (1996: 61) argues, it is a result of the various ethics that have developed in the western world since the 17th century, and which have been formed by various political, religious and ethical trends. For instance, Biblical passages were often used by political and religious leaders throughout the 18th and 19th centuries to assert the supremacy of humankind and, especially, the right of the white races to exploit and alter the natural landscape; thus, e.g., the Judeo-Christian mandate of Genesis I, 28, was cited, telling mankind to take possession of nature: "Be fruitful and multiply, and replenish the earth and subdue it". This passage was, in fact, quoted by the Puritan John Winthrope when he left England for Massachusetts on the Arabella in 1629; as Merchant points out, it "reinforced God's command to transform nature from a wilderness into a civilization" (Merchant 1996: 66; see also Nöth 2001a). 
Merchant sees the global ecological crisis as a result of "deepening contradictions generated between the dynamics of production and ecology and by those between reproduction and production" (1996: 10-11). However, since these contradictions are linked to the cultural, historical and political background of each particular country, the environmental problems in each country need to be investigated separately, linked as they are to a particular prevalent valuation of nature. This is also true of models and concepts of nature in the creative arts whose representations of the interactions between humans and their natural environment reflect the prevailing system, at the same time as they often move at the forefront of paradigmatic change, creatively conceptualizing new scientific and philosophical thoughts and communicating them to a larger audience. Hence, the arts have, in turn, reflected the mechanistic worldview of Cartesian dualism ${ }^{1}$; the Romantic view of nature as mysterious, resourceful and communicative; or, following Darwin's evolutionary theories, the naturalist view of nature as a battlefield on which only the fittest survive. In contemporary literature, the advances of postmodern science and, in particular, chaos theory have radically changed the view of the relationship between humankind and nature by introducing notions of randomness, plurality and uncertainty.

This is particularly pertinent to concepts of nature and "wilderness" in Canada where the wilderness includes vast tracts of forests, lakes and an Arctic North, which has led to a distinctively Canadian relationship between Canadians and their natural environment. The change in the literary representations of interactions between humankind and the environment in Canadian fiction - from the "double vision" resulting from the view of the wilderness both as a threatening Other and free space, to the view of threatened nature as a means of identification; and finally, as a postmodern place of transgression and possibility - invites questions about both the semiotic threshold between nature and culture, and about the function of boundaries in the constitution of identity.

${ }^{1}$ Carolyn Merchant (1996: 66-67) argues that what she calls "egocentric ethics" is rooted in the 17th century philosopher Thomas Hobbes' notion of nature as a common resource for which everyone competes. 


\section{2. "Wilderness" as the cultural Other}

Traditionally, "wilderness" has been seen as negative and primitive in relation to civilization and culture. In its original sense, "wilderness" denoted a "wild or uncultivated region or tract of land, uninhabited, or inhabited only by wild animals" (which is implied by its etymological origin, OE wilddéor, wild beast and its concrete sense, the suffix "ness", from OE nes) or a desolate "tract of solitude and savageness" (OED). Mostly, "wilderness" has been considered the binary opposition to culture, as an outside "non-culture", which threatens cultural space with chaos and disorder.

Yurij Lotman (2001: 124-125) describes the relationship between culture and non-culture in binarisms, on the one hand, and in topological categories, on the other. According to his localistic theory of the structures of semiotic space, the processes in culture are determined by the semiosphere, which is a space analogous to the biosphere marked by heterogeneity and held together by binarism and asymmetry. Hence, culture functions as a sign system against the background of a non-culture, a relationship Lotman (ibid.: 140) depicts in metaphors, such as inside and outside, and center and periphery. The center, for instance, is the place of cultural values where cultural texts are generated and culturally "correct" norms are determined whereas, at the periphery, culture is threatened by chaos and disorder. At the same time, it is this tension that makes the periphery into the place of creative innovation, which will eventually also transform the center of a particular culture.

In the same way, semiotic and cultural individuation is constituted by boundaries creating an internal semiotic space in opposition to external space. Hence, the boundary is the "outer limit of a first-person form", the space which is "ours", "my own", "cultured", or "safe", in contrast to "their space", which is "other", "hostile", "dangerous" and "chaotic" (Lotman 2001: 131).

Lotman's localistic approach seems very apt for descriptions of the Canadian view of the wilderness as the "hostile ", "dangerous" and "chaotic" Other that Lotman (2001: 131) suggests. Unlike the US Americans, who included the concept of "wilderness" in their foundational myths, which Max Oelschlaeger has investigated in his impressive The Idea of Wilderness, Canadians have traditionally had a problematic relationship with their natural environment. This is partly for 
natural reasons: while the heartland of the United States is one of the world's most fertile regions, Canada consists of one of the "earth's most ancient wildernesses and one of nature's grimmest challenges to man and all his works", as the Canadian historian W. L. Morton (1972: 4-5) puts it. Morton calls attention to the fact that the famous comment by Jacques Cartier, Canada's "discoverer", that Canada was "the land that God gave Cain" has never been seriously contested; instead, "[t]he main task of Canadian life has been to make something of this formidable heritage". Morton's ironic comment on a particularly Canadian response to nature would explain how the awareness of this untouched and seemingly empty nature, which surrounds the populated areas in the south and continues endlessly northwards, has led to a distinctively Canadian concept of "wilderness": one which not only denotes a geographical location and functions as a spatial metaphor, but which is also Canada's most popular cultural myth. ${ }^{2}$ Yet it is a European myth, mainly created by the European explorers, settlers, missionaries and soldiers who were unable to read the signs of a nature that was foreign to them, and who conceived of the wilderness they encountered as a threatening Other. Seen only in negative terms, wilderness is the natural "disorder" which upsets the cultured environment, a space outside the social order and Christian morals that is there to be "ordered" or exploited, or both; yet, at the same time, nature also means freedom from the constraints of social rules and regulations. There are thus two readings of the signs of nature, resulting in a strangely ambivalent "double vision" of the wilderness. ${ }^{3}$

This "double vision" also extends to descriptions of the indigenous population, where Native people are rendered either good or bad, with the whites being the norm. Drawing attention to this fact, Margaret Atwood (1995: 39) points out that "[t]he Other is frequently a dump-

${ }^{2}$ According to Atwood in Strange Things: The Malevolent North (1995: 19), it is above all popular lore and popular literature that "established early that the North was uncanny, awe-inspiring in an almost religious way, hostile to white men; that it would drive you crazy and finally claim you for its own ".

${ }^{3}$ As Shelagh Grant (1989: 23) has pointed out, in Canadian texts from the 19th century, the North is a "north of the mind, representing challenge, adventure, enchantment, escape, and solitude", inspired by European Romanticism. On the other hand, Northrop Frye (1977: 31) labels the 19th century Canadian relationship with nature schizophrenic, "the sense of loneliness and alienation urgently demanding expression along with a good deal of prefabricated rhetoric about the challenge of a new land and the energetic optimism demanded to meet it". See also MacLulich (1988: 122), who suggests that Canadian representations of the wilderness "dwell on the process of settlement, in which European or "civilized" values are imposed on the native landscape". 
ing-ground for anxieties", at the same time as it functions as "a way of unloading our moral responsibilities by defining other people as, by nature, better behaved than we are". Owing to the ignorance of the wilderness and its inhabitants, the dialogue necessary for exchange and understanding of this Otherness did not take place in the early settlements, although Native guides were often used for explorations into the wilderness.

A striking example of the difference in views of nature can be seen in Native art and handicraft, where carvings in wood and stone, birch bark scrolls and masks demonstrate an integrated world view, with an integral relationship between nature and culture and between material and spiritual worlds. In contrast to this pansemiotic and pantheist world where the threshold between nature and culture is practically non-existent, the new settlers worked hard to transform the natural landscape into a cultural one. Hence, as Brian Osborne (1988: 163) points out, the great battle was against the wilderness and, in particular, the vast tracts of forest, with the aim of replacing the wilderness by the "geometrical order of the civilized and domesticated world", i.e., transforming it into a European representation of nature in the New World.

\section{3. "Wilderness" in early English Canadian literature}

The view of the natural environment as a raw, alien and undisciplined Other, as the brute force of Secondness, is hence something that distinguishes the early Canadian relationship with nature from the American one, with its romantic implications of a Paradise Lost. In American wilderness romance, for instance, the encounter with nature entails a spiritual journey from which you emerge reconciled with nature and with yourself. This is not so in the Canadian versions of the genre, as Gaile McGregor has convincingly shown in her analysis of the function of American and Canadian wilderness romance. Locating it at the interface between civilization and the wilderness, "precisely on the line where those two realities and those two states of mind come together" (ibid:: 3), ${ }^{4}$ she compares James Fenimore Cooper's

\footnotetext{
${ }^{4}$ McGregor also makes the interesting observation that, because Canadians refused to reconcile themselves with nature, it was neutralized and was never sentimentalized to the same extent as in American culture, where it is tied up with nostalgic values (1985: 73).
} 
The Last of the Mohicans (1826) and Major John Richardson's Wacousta, or the Prophecy: A Tale from the Canadas (1832). In Wacousta, which, according to James Reaney (1991: 540), was written directly as an answer to Cooper's novel, the respective responses to nature and the wilderness are grounded in essentially divergent cultural features. Whereas Cooper's wilderness romance has man engage with a nature that can be both dangerous and benevolent, in Richardson's story about the last of the Indian uprisings against the British Forts Detroit and Michilimackinac, descriptions of nature are virtually nonexistent. This suggests that, although he situates the plot in the midst of wilderness, he does not seem to "see the landscape at all": far from of dealing with it, he not only ignores but even denies it. As MacGregor argues, "while the wilderness - nature — is a major component in the world of Cooper's books, in Wacousta it is barely evoked at all" (1985: 4-5).

Throughout Richardson's novel, it is thus what the critical theorist Northrop Frye (1971: 226) labeled "the garrison mentality" that prevails: the "over-imaginative" soldiers are terrified of venturing into the hostile forest, "with their fancies of Indians behind every tree". The civilization/wilderness opposition which, in Cooper's novels, operates in terms of two opposite poles functions differently in Wacousta: although they still stand in opposition to one another, they form a static, circular structure in which no reconciliation between man and nature is possible, in contrast to the dynamic process of Cooper's novel, where Natty Bumppo is part of the same interface between man and nature - "the primitive or 'natural' man who serves as mediator between the civilized world and the wilderness 'other' (McGregor 7-8). In Wacousta, there is no such semiotic activity, a fact which I would suggest is rooted in the colonial situation. With the cultural center in Britain and not in Canada, the settlers' and soldiers' attempts to impose European norms on a New World environment saw no place for the category of "wilderness": indeed, it is judged "non-existent", as is confirmed by the absence and denial of nature in Wacousta.

The lack of mediation between civilization and wilderness leads Northrop Frye (1971: 142-43) to suggest that, because the Canadian Confederation was formed so soon after to the pioneer period, "it was still full of wilderness". In contrast to the steadily westward-moving American frontier, the European travelers entering Canada via the Gulf of St. Lawrence were "engulfed" by the wilderness, whose frontier "was all around one, a part and a condition of one's whole imagi- 
native being". 5 Thus, Frye, too, takes a localistic approach to the problem of Canadian identity and its close connection with the natural environment, and asks if "any other national consciousness has had so large an amount of the unknown, the unrealized, the human undigested built into it?".

\section{The loss of "wilderness"}

This negative view of nature was still fairly predominant when the ecological crisis triggered the environmental movement in the 1960s - with the publication of Rachel Carson's Silent Spring (cf. Hoffmeyer 1996: 142) — which coincided with English Canada's search for a national identity. Carson's bestseller even had a Canadian fictional equivalent, in the form of Margaret Laurence's short story, "The Loons", in which Laurence uses the loon's cry as a semiotic node for the Canadian relationship with the wilderness and its indigenous inhabitants, and for the destructive consequences of human encroachment on nature: the Indians become addicted to drugs and alcohol, and the loons vanish, as a result of mercury poisoning, acid rain and commercial trapping nets.

At this point in time, Canada was attempting to define itself against its former mother country and the overwhelming influence of the USA. At the same time, the Quebec Separatist movement threatened to undermine a historically fragile national unity. The idea of endangered nature and, especially, of threatened wilderness suddenly became synonymous with Canada's own cultural situation, a perception that is reflected in the fiction of the 1960s and the 1970s.

This tension is something that Margaret Atwood develops in her novel Surfacing, where she radicalizes the boundary between nature and culture by juxtaposing it to the one between the Self and the Other, in terms of both cultural and personal identity formation. As the daughter of an entomologist, she had spent a great deal of her childhood in the wilderness of northern Ontario and Quebec and knew wilderness from personal experience well before she encountered it as a cultural myth. This early experience is something to which she has come back repeatedly in her fiction, and it is within this dual context

${ }^{5}$ Frye's socio-historical and mythopoeitic theories have been criticized as being too culturally nationalist and too reductive; however, many of his observations still seem valid. 
that she writes. ${ }^{6}$ Placing her narrator at the interface between the English-speaking province of Ontario and the French-speaking province of Quebec, she literally exemplifies Lotman's (1990: 142) observation that semiotic processes are intensified in the frontier areas, since the boundary is the domain of bilingualism. "Now we're on my home ground, border country", says the nameless narrator (Atwood 1989: 8 ), when she and her companions see the bilingual border sign in the northern wilderness. With 'WELCOME' on one side and 'BIENVENUE' on the other, the road sign both indexically denotes the border between the two provinces, at the same time as it iconically mirrors the deeply felt cultural chasm between the English-speaking and French-speaking populations, and the problem of national identity although the hybrid election slogans along the road demonstrate a coexistence that, at least on the surface, seems to function.

By using signs of ecological significance, such as birch trees dying from acid rain and lakes being emptied of fish, as indices of a Canadian wildlife threatened by "others" ("Americans"), Atwood's second novel, which quickly achieved cult status when it first appeared in 1972, opened a discussion of what relationship between humans and nature is necessary to ensure an ecological balance. By unmasking nationalist assumptions - showing that the "Americans" the narrator suspects are in fact Canadians - she demonstrates that the roots of the environmental crisis transgress national boundaries. Indeed, "the great Cartesian error" is not only the cause of the ecological crisis but also of the predicament of modern civilization, of the exploitation of humankind and nature, the destructive split between mind and body and between nature and culture, and the ensuing alienation experienced by modern man.

Atwood rewrites this relationship by having her nameless narrator transgress the semiotic threshold between nature and culture, as she embarks on a journey into nature in order to accept the natural within her. The narrator's withdrawal from human company leads her to mis-

${ }^{6}$ As Coral Ann Howells (1996: 22) has pointed out, one of Atwood's first refigurings of the wilderness was her poetic sequence The Journals of Susanna Moodie (1970), a rewriting of Roughing It in the Bush (1852), the autobiography of the Victorian pioneer Susanna Moodie. In these poems, Atwood shows how Moodie's initial fear of the Canadian landscape, which she first sees as alien and threatening, changes into a reading of the wilderness as a harmonious world that teaches her its secret language. Howells also draws attention to the much darker prospects of survival of the human race discussed in Atwood's more recent works, such as Wilderness Tips (1991), which shows a clear shift away from the optimism of the 1970s (1996: 33). 
trust signs of human culture, especially language, which she sees as deceptive and manipulative, and instead, to orient herself by nonlinguistic signs which she interprets as "rules" informing her of what she must or must not do: she is "not allowed to go back in that cage, wooden rectangle [her parents' cabin]. Also tin cans and jars are forbidden; they are glass and metal. The outhouse is forbidden so I leave my dung, droppings on the ground, all animals do that" (Atwood 1989: 213-15).

The narrator's interpretation of everyday reality as a set of "rules" could be seen as a symptom of schizophrenia; but Atwood has it mark the narrator's entry into the primitive rites of initiation that will enable her to enter a more visionary state. Her attempts to merge with nature by renouncing human cultural practices has her thus regard nature as entirely semiotic: she has a hallucinatory feeling of her body dissolving and of becoming part of the biogenetic processes of the wilderness. Moving back through the phases of evolution, she has a vision of the Amerindian primeval forest of long ago:

The forest leaps upward, enormous, the way it was before they cut it, columns of sunlight frozen; the boulders float, melt, everything is made of water, even the rocks. In one of the languages there are no nouns, only verbs held for a longer moment.

The animals have no need for speech, why talk when you are a word.

I lean against a tree, I am a tree leaning...

I am not an animal or a tree, I am the thing in which the trees and animals move and grow, I am a place. (Atwood 1989: 216-17)

Seen from a Peircean viewpoint, Atwood has her narrator enact the development of the human mind within nature: her poetic images call up a world moving back to an early state of flow and chance, transforming matter back into energy, from the forest's "columns of sunlight frozen" to the boulders that "float, melt", until "everything is made of water, even the rocks". Her description of this primordial state recalls C.P. Peirce's synechistic theory that matter is mind frozen (CP 6.2777); as Winfried Nöth (2001b) points out, according to Peirce's "anti-dualism and evolutionism" (Santaella Braga 2001), mind and semiosis are prior to matter: "mind comes first, matter last". Peirce's belief in the principle of continuity between mind and matter implies that the self must be included in reflections on one's environment, since mind and matter have evolved together. By having her narrator's hallucinatory experience take place both on a genetic and on a semiotic level, as she goes back to the very beginning of time, Atwood represents her narrator's voyage of self-discovery as an evolu- 
tionary process, abolishing the semiotic threshold by showing that mind exists not only in humans, but also in their natural environment.

Yet, becoming part of nature means dissolving the self, and the narrator ultimately pulls back from the idea of unification (even in her symbiotic unity with nature, she still says "I am"). Instead, after taking the Romantic notion of a communicative nature to its almost parodic extreme, Atwood has her re-emerge from this experience; "break[ing] surface", as it were, from a descent into the realm of biogenetic processes and mythic time to "stand[...] ..., separate again" (1989: 217). This recovery is represented as a series of shifts in perception, where a carved fish object and a magic fish rock painting mingle with her interpretation of the natural sign of a fish jumping out of the water as a greeting from her drowned father:

From the lake, a fish jumps.

The idea of a fish jumps.

A fish jumps, carved wooden fish with dots painted on the sides, no, antlered fish thing drawn in red on cliffstone, protecting spirit. It hangs in the air suspended, flesh turned to icon, he has changed again, returned to the water. How many shapes can he take.

I watch it for an hour or so; then it drops and softens, the circles widen, it becomes an ordinary fish again. (Atwood 1989: 224)

Atwood's very detailed description of sign interpretation recalls Peirce's theory of the "real" or dynamical object, whereby an object which exists "in reality" is nevertheless inaccessible to our mind, or can only be accessed by approximation (CP 1. 538; cf. Nöth 2001a). The dynamical object resists interpretation and can even determine the sign in relation to its object whereas the immediate object is the mental representation of this object in the form of our previous knowledge of the world. Atwood's text plays with the difference between the dynamical and the immediate object, between "the Reality which in some way contrives to determine the Sign to its Representation"(CP 4.536) and the already present mental representation of this object, as she represents the narrator's recovery in a series of changes in perception and sign interpretation - the dynamical object of a "real" fish jumping, which awakes earlier mental representations of "fish", such the very concept of "fish", or its various representations, e.g., a wooden handicraft object, an Indian rock painting, or her drowned father, her protecting spirit, until it becomes a "normal" fish again. This return to "normal" perception is the beginning of her regaining her "self": by forming a coherent story of her past experience, she stabilizes her sense of self and re-enters society as an interpreting sub- 
ject. Thus, in this novel, the wilderness becomes the site of spiritual revival of the self and of the reconstruction of identity, at the same time as it questions traditional wilderness concepts and myths and advocates a deeper understanding of the fundamental relationship between humankind and nature.

\section{5. "Wilderness in postmodernity"}

The idea of wilderness as a place of creative innovation is even more pronounced in Aritha van Herk's "geografictione" Places far from Ellesmere, which was published in 1990, at a time when the "cultural nationalism" of the 1970s had faded, and Canada was well on its way to becoming a multicultural society. The Canadian concepts of "wilderness" had widened and diversified, and had become regional, Native, ethnic, or gendered instead - positions perceived as being marginal, which Linda Hutcheon (1988: 3) considers typical both of postmodernism and of Canadian culture, which has always had to define itself against more powerful centers. However, as Hutcheon argues, the margin is "no longer conceived of only as a place of transgression" but also as "the place of possibility", because "[t]he periphery is also the frontier" where borders and limits are challenged and explored. This sounds very similar to Lotman's (1990: 136) notion of boundaries, which he calls "the hottest spots for semiotizing processes": the notion of boundary is ambivalent, simultaneously separating and uniting; it is the place where what is "external" is transformed into what is "internal":

Since the boundary is a necessary part of the semiosphere and there can be no 'us' if there is no 'them', culture creates not only its own type of internal organization but also its own type of external 'disorganization.' (Lotman 2001: 142)

Aritha van Herk refigures these boundaries into an exploration of the processes behind the cultural representations of landscape and wilderness, and of women. By self-consciously setting the main part of her exploration on Ellesmere Island, one of the most remote places on earth - it is situated in the Canadian High Arctic, on the very edge of cartographic space - she challenges borders as limits, both in a geographical and in a literary sense. An extraordinary work that eludes genre distinctions, the fragmentary text of Places far from Ellesmere 
challenges traditional notions of narrative by blurring the distinctions between nature and discursive space.

In van Herk's novel, the dialogic semiosis between humankind and landscape is shown to be fundamental to the formation of self-identity. Her exploratory reading of both "wilderness" and civilized discursive space is structured as an investigation of four "explorations sites": her home village of Edberg; Edmonton, her university town; Calgary, where she currently lives; then, finally, she travels to Ellesmere Island in the extreme Arctic, with her male companion, himself an exploration geologist, and a Penguin Classics copy of Anna Karenina. Van Herk's investigation of the interrelations between humans and landscape in the Canadian West and North turns into an exploration of how the identity of these landscapes has been altered by civilization and, in turn, has formed those living there. Her description of the Canadian West ties in with Northrop Frye's (1971: 224) suggestion that Canadian civilization expresses "the conquest of nature by an intelligence that does not love it": by forcing the country into geometrical survey grids, "throwing down the long parallel lines of the railway, dividing up the farm land into square-line sections and concession line roads". In Places far from Ellesmere, the narrator describes her home village of Edberg as one such "square grid of section lines, homesteads, settlements" (1990: 14), and Edmonton, her university town, as a former fort, the stronghold of the Hudson's Bay Company, which for centuries ruthlessly exploited the North. Calgary, whose recent oil boom has resulted in "grit-blown monoliths ... [that] stand for death, another Stonehenge in haphazard phalanx" (ibid.: 66), has transformed the wilderness into city monuments, with the pre-historic fossils embedded in the stone walls of the buildings signifying the conquest and death of nature.

By contrast, van Herk's description of Ellesmere, which she pits against this image of death and stasis, is a celebration of processes and of perpetual movement, like that of what she calls the "puzzle-ice" of the arctic:

Puzzle-ice. Mesmerizing, its slow wash and float, its conundrum melting and reappearance. The chunks themselves islands and the arctic ocean between a liquid light. (Herk 1990: 88)

The constant motion of this arctic landscape, which eludes fixed boundaries and territories, forces the narrator to learn how to deal with chaotic and self-regulatory systems, such as the arctic ice, and to read their signs in order to survive: walking on Ellesmere is like "always 
reading an eternal book" (1990: 131), but one whose unpredictability forces you into continuous adjustment. Instead of fixity and stasis, van Herk's narrator seems to prefer motion and mobility, such as her own walking, the nomadic population's way of life, or the constant movement of the "puzzle-ice", as a process of which she becomes part and which parallels her own quest for new modes of interpretation and expression.

By juxtaposing her narrator's reading of the natural signs of the Arctic with her re-reading of Tolstoy's Anna Karenina, van Herk has her text represent the process of self-interpretation as dialectic interplay. The boundary location becomes significant, because "[o]nly the north can teach what reading means, and you are a woman in the north, reading a woman written by a man to whom women were a mystery ..." (1990: 132). Hence, her narrator's dialogic reading of Anna Karenina — she silently discusses Tolstoy's novel and questions his authority by demonstrating that his story about Anna Karenina is pervaded by the 19th century's double morals - which is paralleled with her own experience on the island, has the text enact the process of figuring the "self" in a continuous dialogue:

But whose invention is she? Tolstoy's? The nineteenth century's? Russia's? The novel's? Yours? She is the north's invention, her figure only dreamable when the eye swings towards the polar star. But how then to read her? Is it possible to read her in the south, from the south? In that blindly south-faced reading, is it possible to read at all? ... You are closer to Russia than to home: reading is a new act here, not introverted and possessive but exploratory, the text a new body of self, the self a new reading of place ... the closest you can get to reading and still know story is this undiscovered place, the farthest possible reach of all reaches, this island paradise, this un/written northern novel, this desert un/kingdom. (1990: 113)

The dialogic exchange corresponds to the Peircean idea of unlimited semiosis, where "thinking always proceeds in the form of a dialogue - a dialogue between different phases of the ego - so that being dialogical, it is essentially composed of signs" (CP 4.6). Peirce's idea of thinking as dialogue also recalls Michail Bakhtin's notion of dialogism as a fundamental principle for the constitution of identity. According to Bakhtin, the self can only see itself from the imagined perspective of an Other. Otherness becomes "the ground of all existence and [...] dialogue the primal structure of any particular existence" (Clark, Holqvist 1984: 65). Hence, the constant crossing of the boundary between the inner I and alterity creates a relationship 
between the self and all that is other: "The Bakhtinian self is never whole, since it can only exist dialogically" (ibid.).

Van Herk plays with this notion by having the intimate secondperson pronoun "you" function both as an Other and as a self-referring second-person address, which blurs the distinction both between self and Other and between the roles of narrator and reader, in the same way as she becomes part of the island, where the interaction between body and environment seems to be one of "pleasure" and "seduction". Thus, drawing water from a river becomes an integrated, synesthetic movement of "buckets and waters and stones and the muscles of shoulder and arm" (Herk 1990: 109), with the parataxis transmitting the feeling of interacting with nature.

Like Atwood, Herk fictionalizes autobiography in order to explore the close relationship between the construction of identity and an existential interaction with nature; and like Atwood, she uses this "journey to the interior" (which takes place on an island in both works) as a device for the cultural mapping of the relationship between humankind and nature. Defining the act of writing as "grappl[ing] with the urgency of transforming reality into a sign" (1996: 229), she has this "transformation of reality" make "the text a new body of self, the self a new reading of place" (1990: 113) in order to map both civilized space, with its history of the human exploitation of natural resources, and the unmapped, undocumented arctic wilderness of Ellesmere Island. Thus, by exploring literary and geographical landscapes by mingling cultural and natural signs, carefully avoiding the "gridlines" laid out by traditional appropriations of literature and landscape, van Herk uses the "empty" space of Ellesmere to break free of the constraints of mapped and civilized space and to negotiate new identities beyond the traditional boundaries between nature and culture.

To conclude, in the face of a continually shrinking natural environment, our perception of the semiotic threshold between nature and culture is becoming increasingly important for the survival of the wilderness and its various ecosystems. Literature, which automatically forces the reader to take the position of an Other, can both reflect and induce an understanding of "outside" or "peripheral" categories such as the wilderness, and help develop an ecosemiotic orientation in order to find new ways of reading the signs of a nature of which we are a part. Hence, the Canadian context of Atwood's Surfacing demonstrates the complexity of the relationship between nature and identity, and its implications for a Canadian national identity, whereas van Herk's exploration of both discursive space and wilderness at the lim- 
its of cartographic space suggests new ways of articulating shifting positions both in fiction and in nature, and an urge to move away from a specifically Canadian to a more global awareness of our natural predicament.

\section{References}

Atwood, Margaret 1970. The Journals of Susanna Moodie. Toronto: Oxford University Press.

- 1972. Survival: A Thematic Guide to Canadian Literature. Toronto: House of Anansi.

- 1989. Surfacing. Toronto: Fawcett Crest.

- 1991. Wilderness Tips. London: Bloomsbury.

- 1995. Strange Things: The Malevolent North in Canadian Literature. Oxford: Clarendon.

Clark, Katerina; Holquist, Michael 1984. Michail Bahktin. Cambridge: Harvard University Press.

Cooper, James Fenimore 1985. The Leatherstocking Tales. Vol. 1. New York: Literary Classics of the United States. 2 vols. 3-1349.

Frye, Northrop 1971. The Bush Garden. Toronto: House of Anansi.

Grant, Shelagh 1989. Myth of the North in Canadian ethos. Northern Review (3/4): 15-37.

Herk, Aritha van 1990. Places far from Ellesmere. Red Deer: Red Deer College Press.

- 1996. The map's temptation or the search for a secret book. Journal of Commonwealth Literature 31(1): 129-136.

Hoffmeyer, Jesper 1996. Signs of Meaning in the Universe. Trans. by Barbara B. Haveland. Bloomington: Indiana University Press.

Howells, Coral Ann 1996. Margaret Atwood. London: Macmillan.

Hutcheon, Linda 1988. The Canadian Postmodern: A Study of Contemporary English-Canadian Fiction. Toronto: Oxford University Press.

Kull, Kalevi 1998. Semiotic ecology: Different natures in the semiosphere. Sign Systems Studies 26: 344-371.

Laurence, Margaret 1966. The Loons. A Bird in the House. Toronto: McClelland \& Stewart.

Lotman, Yurij 2001. Universe of the Mind: A Semiotic Theory of Culture. Trans. by Ann Shukman. London: Tauris.

MacLulich, T. D. 1988. Between Europe and America: The Canadian Tradition in Fiction. Toronto: ECW.

McGregor, Gaile 1985. The Wacousta Syndrome: Explorations in the Canadian Langscape [sic]. Toronto: University of Toronto Press.

Merchant, Carolyn 1996. Radical Ecology. New York: Routledge.

Moodie, Susanna 1989. Roughing It in the Bush. Toronto: McLelland \& Stewart.

Morton, W. L. 1972. The Canadian Identity. Toronto: University of Toronto Press. 
Nöth, Winfried 2000. Handbuch der Semiotik. (2nd ed.) Stuttgart: Metzler.

- 2001a. Ecosemiotics and the semiotics of nature. Sign Systems Studies 29(1), (this vol.).

- 2001b. Semiogenesis in the evolution from nature to culture. To appear in Violi, P.; Ala, M. (eds.), Origin of Semiosis. Turnhout: Brepols.

Oelschlaeger, Max 1991. The Idea of Wilderness. New Haven and London: Yale.

Peirce, Charles S. 1931-1958. Collected Papers. Vols. 1-6 (C. Harthorne, P. Weiss, eds.), vols. 7-8 (A. W. Burks, ed.). Cambridge, Mass.: Harvard University Press. [Quoted as CP]

Reaney, James 1991. Afterword. In: Reaney, James Wacousta. Toronto: McClelland \& Stewart, 540-544.

Richardson, John 1996. Wacousta, or the Prophecy: A Tale of the Canadas. Toronto: McClelland \& Stewart.

Santaella Braga, Lucia 2001. 'Matter as effete mind': Peirce's synechistic ideas on the semiotic threshold. Sign Systems Studies 29(1), (this vol.).

Sebeok, Thomas 1991. A Sign is Just a Sign. Bloomington: Indiana University Press.

\section{Дикая природа в экосемиотической перспективе}

“Дикая птрирода" (wilderness) является концегтом, который в последние годы существенно преобразился. В результате глобальных маштабов уничтожения птриродной среды, которому сопутствует и уничтожение дикой природы и ее разных экосистем, дикая природа из изначального отрицательного Другого превратилась в объект всеобщего внимания. "Дикую природу" не воспринимают более просто как место, а как категорию, которая тесно связана с развитием человеческой культуры, и экологические знаковые процессы которой требуют внимательной интергтетации.

В результате человеческой деятельности и репрезентации природа является политизированной. Модели природы и ее изображение в искусстве, в той мере, в какой они выражают властвующие идеологии, указывают на тесную взаимосвязь природы и культуры. Это характерно прежде всего для концепций природы в Канаде, где к дикой природе относится множество озер, лесов и арктические северные территории, в связи с чем выработалось особенное "канадское" отношение к природе. Изменения в литературных описаниях отношений между человеком и окружающей средой в канадской прозе вызывают вопросы о роли семиотического порога и границ между культурой и природой в формировании идентитета. 


\section{Metsik loodus ökosemiootilises perspektiivis}

"Metsik loodus" (wilderness) on kontsept, mis on viimastel aastatel läbi teinud põhjaliku muutuse. Tingituna looduskeskkonna hävitamise globaalsetest mastaapidest, millega kaasneb ka metsiku looduse ning selle erinevate ökosüsteemide hävitamine, on metsik loodus algsest negatiivsest Teisest muutunud avaliku tähelepanu objektiks. Kasvav teadlikkus looduslike alade hävitamise tagajärgede pöördumatusest on tinginud suurema tundlikkuse meie loodusest sõltuvuse suhtes; ühtlasi ei mõisteta "metsikut loodust" enam mitte kui lihtsalt kohta, vaid kui kategooriat, mis on tihedalt seotud inimkultuuri arenguga.

Inimese tegevuse ja representatsioonide tulemusena on ka loodus politiseeritud. Looduse mudelid ja selle kujutamine kaunites kunstides, kuivõrd need väljendavad valitsevaid ideoloogiaid, viitavad seetõttu kindlale kultuuri suhtele loodusega. See kehtib eriti looduse kontseptsioonide kohta Kanadas, kus metsikus looduses leidub ulatuslikke metsa- ja järvealasid ning arktilisi põhjaalasid, mille tõttu on välja kujunenud eriline kanadapärane suhe kanadalaste ja nende looduskeskkonna vahel. Muutused inimese ja keskkonna vaheliste suhete ilukirjanduslikus kujutamises Kanada proosas - alates metsiku looduse kahetisest tajumisest nii ähvardava Teise kui ka vaba ruumina kuni ohustatud loodusega identifitseerumise ning selle mõistmiseni postmodernse piiriületuste ja võimaluste kohana - tekitavad küsimusi nii looduse ja kultuuri vahelise semiootilise läve kui ka piiride rolli kohta identiteedi kujunemisel. 